\title{
Relationship between Social Support and Psychological Well-Being of the Final Year Students
}

\author{
Muji R. Saputra', Listyati Setyo Palupi ${ }^{r^{2} *}$ \\ ${ }^{1}$ Personality and Social Psychology Department, Faculty of Psychology, Airlangga University, \\ Surabaya, Indonesia \\ ${ }^{2}$ Health and Environmental Sustainability Research Group, Faculty of Psychology, Airlangga \\ University, Surabaya, Indonesia \\ ${ }^{3}$ Addiction Study Centre, Airlangga University, Surabaya, Indonesia
}

\begin{abstract}
Research shows that final year students experience stress when they work on their thesis. This situation has affected their psychological well-being. According to Ryff psychological wellbeing is a condition of someone who is free from pressure and problems. Thus, this study aims to determine the relationship between social support and psychological well-being of final year students who are working on a thesis. This research was conducted at Airlangga University. This study uses a quantitative approach. This research was conducted on 156 students that are working on their thesis at Airlangga University. Data obtained using a survey method that uses a measure of social support scale developed by Zimet and psychological well-being scale developed by Palupi in the journal Studia Universitatis Maladaviae. The data analysis technique used in this study is Pearson Product Moment. The results of the analysis show a correlation of 0.760 which means there is a relationship between social support and psychological well-being of the final year students who are working on their thesis.
\end{abstract}

\section{Introduction}

Students as members of an institution of higher education are required to have independence and responsibility to complete academic assignments that have been determined, in order to achieve the competencies of graduates expected by the universities which are places to study. The academic assignment is the completion and achievement of the determined study, the completion of the lecture, the practicum and the preparation of the thesis.

* Corresponding author: listyati.palupi@psikologi.unair.ac.id 
Based on the results of interviews conducted by Etika[3], she concluded the difficulties of students who are experiencing a lot of problems such as insomnia, loss of appetite, pain, lack of rest time, lack of funds, lack of motivation, sometimes personal problems interfere with the mind so it does not concentrate in making thesis assignments. Difficulties in preparing thesis including difficulties in compiling the formulation of the problem, determining the title, conceptualizing the contents of the thesis, writing techniques, content, research methods used, and lack of references, as well as difficulties in pouring the writing into the thesis script.

There are various things that become obstacles in the work of thesis, including: boredom in working on thesis, a long process of collecting data, difficulty pouring thoughts into writing, difficulty in dividing time between working on thesis with other activities for example work and lack of ability in English to read the book literature used [4]. As a student in tertiary education, individuals will be faced with more demands compared to the education that was taken before. The workload will also become heavier in the higher semester. Undergraduate students who have reached the final year and have taken the specified number of SKS will eventually face a final project or also called a thesis [5]. The students who working their thesis will mentally and physically depressed [6], it makes individuals have low well-being because good well-being is a condition someone who has the ability to be free from stresses and mental problems, as well as accepting himself or his life in the past (self-acceptance), development or personal growth (personal growth), the belief that his life is meaningful and has a purpose (life in life), has a positive relationship quality with others (positive relationship with others), the capacity to manage their lives and the environment effectively (environmental mastery), and the ability to determine their own actions (autonomy). Which means that if students do not have the ability to be free from physical and mental stress, their well-being is considered low.

Someone with good psychological wellbeing can deal with disturbances that arise from the problems experienced. However, if a person's psychological wellbeing is lacking, then when faced with a difficult problem it is easier to experience depression [6].

The problem of psychological well-being is becoming increasingly common among students today. High levels of mental stress have been reported among students from various departments in higher learning institutions [7]. In a study Sari [8], that interviewed students with students in one of the Engineering Faculties at Diponegoro University further strengthened the data that final-year students were preoccupied with by repeating many courses, the average of the most repeated subjects was courses in the semester three and four. The results of interviews with students who still survive, it is known that repeated courses are required two or three times or even up to five times to be able to graduate from difficult courses. Not all of the time to repeat courses can be done in the next semester, because not all courses are always in each semester.

The existence of social support problems is considered to hamper the achievement of psychological well-being in students. This is in accordance with the opinion of Yasin [9], social support can reduce the psychological impact of problems faced by students who then bring themselves students to achieve psychological wellbeing. So it can be concluded that if students lack social support, it will hamper the achievement of psychological well-being in these students.

In research by Sarafino [10] said that interacting with others can modify or change individuals about negative events to be positive. Differences in social support provided and the factors that influence it can affect psychological well-being in students who are working on thesis. Every student will experience something different in terms of providing social support. This attracts the attention of researchers who want to see whether there is a relationship between social support and psychological well-being in the final year students who are working on their thesis. 


\section{Method}

This research using quantitative method with associated descriptive approaches. This research is located in Airlangga UniversitySurabaya. This subjects of this research are Final Year Student in Universitas Airlangga Surabaya.

The instrument used by researchers consisted of questionnaires. The data collection technique in this study is a survey technique, while the subject taking technique uses NonProbability Sampling. Social support is measured using Multidimensional Scale Perceived Social Support (MSPP) developed by Zimet [11] and Psychological Well Being is measured by Javanese Psychological Well-being Scale developed by Palupi [12]. For data analysis technique author uses the Correlation Pearson Product Moment, a nonparametric statistical technique.

That assisted by IBM SPSS Statistics version 25.0 As a requirement to analyze Pearson product moment correlation, it is necessary to first test the assumption of normality and linearity.

\section{Data and Results}

Table 1. Demographics Characteristics.

\begin{tabular}{lcc}
\hline \multicolumn{1}{c}{ Characteristics } & $\begin{array}{r}\text { Frequency } \\
(\mathrm{N}=156)\end{array}$ & Percentage \\
\hline Gender & 31 & \\
Male & 125 & $19,88 \%$ \\
Female & & $80,12 \%$ \\
\hline Age & 3 & $1,9 \%$ \\
18 & 4 & $2,5 \%$ \\
19 & 16 & $10,2 \%$ \\
20 & 48 & $30,7 \%$ \\
21 & 58 & $37,1 \%$ \\
22 & 19 & $12,1 \%$ \\
23 & 6 & $3,8 \%$ \\
24 & 2 & $1,2 \%$ \\
25 & & \\
\hline
\end{tabular}

Based on data processing, descriptively, Table 1 found that there were 156 subjects. From demographic data based on sex, it is dominated by women as many as 125 people $(80.12 \%)$ while men as many as 31 people $(19.88 \%)$. Based on age, subjects who were in the age range of 22 years had the highest percentage $(37.1 \%)$ or as many as 58 people. Then proceed at the age of 21 years which has a percentage of $(30.7 \%)$ while the smallest is at vulnerable age of 25 years, namely as many as 2 people or only $(1.2 \%)$. 
Table 2. Descriptive Characteristics

\begin{tabular}{lcc}
\hline & \multicolumn{2}{c}{ Variable } \\
\cline { 2 - 3 } & $\begin{array}{c}\text { Psychological } \\
\text { Well-Being }\end{array}$ & Social Support \\
\hline Total Data & 156 & 156 \\
Rata-Rata & 28.82 & 61.28 \\
Std. Deviasi & 4,789 & 9.743 \\
Range & 17 & 37 \\
Min. & 19 & 40 \\
Max. & 36 & 77 \\
Skewness & -0.148 & -0.212 \\
Kurtosis & -1.313 & -1.128
\end{tabular}

Based on table 2 it can be seen that for the Psychological Well-Being variable a minimum value of 19 is obtained, a maximum value of 36 , a mean of 28.82 and a standard deviation of 4.789 . Whereas the social support variable obtained a minimum value of 40 , a maximum value of 77, a mean of 61.28 and a standard deviation of 9,743.

Table 3. Correlation Test Results

\begin{tabular}{lcc}
\hline \multicolumn{1}{c}{ Variable X } & Sig. (2-tailed) & Pearson Correlation \\
\hline Psychological well being & 0,00 & 0.760 \\
$\begin{array}{l}\text { Dukungan_Sosial(Social } \\
\text { Support) }\end{array}$ & & \\
\hline
\end{tabular}

Based on table 3 , there is a strong and positive relationship between psychologic wellbeing and social support $[\mathrm{r}=0.760 \mathrm{n}=156, \mathrm{p}>0.05]$, so the higher social support being is related to the high psychological well-being.

Furthermore it is shown that the significance value is 0,00 (higher than 0,05 ), this means that there was not significance relation between Social Support and Psychological Wellbeing. It is known that Correlation Coefficient is 0.760 , this means that the relation between two variables are high.

\section{Discussion}

This study aims to examine whether there is a relationship between social support for Psychological Well-Being in final year students working on thesis. The author conducts a prerequisite test before looking for a correlation between the two variables, namely the test for normality and linearity. The data is said to have a normal distribution seen based on a significance level of more than 0.05 and the data obtained in this study is 0.061 so it can be said that the data is normally distributed. In addition, another prerequisite test, namely the test of linearity, can also be said to be significant if the value is more than 0.05 , where the significance value in this study is obtained 0.335 , showing this result shows that the variables have a linear relationship and meet the assumptions test requirements for correlation. The researcher conducted a Pearson Product Moment correlation test which was used to determine the direction and strength of the relationship between the two variables studied. 
The results of this study indicate that the variables of social support and psychological well-being have strong correlation. The significant influence between social support variables in predicting psychologic variables well-being is in line with what stated by Teori [4] which in the study said that social support can influence the attitude of students in doing their thesis or final project, because of all kinds of pressure and the obstacles felt by students when working on their thesis.

Correlation test results show that social support $(r=0.760)$ has a level of strong and positive correlation which indicates that if social support is high, the Psychological WellBeing that will be experienced by the individual is also high. This shows that there is a relationship between social support and Psychological Well-Being in students who are doing thesis at Airlangga University.

This research is in line with what was done by Riani [12] who examined the relationship between social support and problem-focused coping with Psychological Well-Being in FIP UNY students. Where in his research found the value of the social support regression coefficient of 0.281 states that any increase in social support by $100 \%$ will increase Psychological Well-Being by $28.1 \%$.

As mentioned earlier that students who work on thesis have several sources of stressors that make individuals experience problems, increasing social support received by individuals can increase Psychological Well-Being. This increase in well-being can reduce the stress experienced by individuals as in research conducted by Gençöz [13] examining the direct and indirect effects of social support on Psychological Well-Being found that there is an influence between social support on depressive symptoms owned by students. Especially support in the form of direct assistance to individuals who have a direct influence to reduce symptoms of depression.

Because the student is often facing the problem when they try to finish their thesis and the problem gonna effect their psychological well-being, so it is show that social support will have positive impact on their psychological well-being.

\section{References}

[1] L. S. M. M. S. P. K. M. W. O. G. \&. M. M. M. Abbeduto, "Psychological well-being and coping in mothers of youths with autism, down syndrome, orfragile X syndrome," American Journal on Mental Retardation, p. 109, (2004)

[2] C. L. \&. A. N. E. Park, "Coping style as a predictor of health and well-being across the first year of medical school," Health psycholog, p. 22, (2003)

[3] N. \&. H. W. F. Etika, "Deskripsi masalah mahasiswa yang sedang menyelesaikan skripsi," KOPASTA Jurnal Program Studi Bimbingan Konseling, p. 3, 2016.

[4] L. Teori, "Hubungan antara distress dan dukungan sosial dengan prokrastinasi akademik pada mahasiswa dalam menyusun skripsi.," 2015.

[5] Y. Syaudah, "Strategi Coping Dan Psychological Well-Being Pada Mahasiswa Tingkat Akhir," Acta Psychologia, vol. 4, pp. 317-328 , 2019.

[6] C. D. \&. K. C. L. M. Ryff, "The structure of psychological well-being revisited," Journal of personality and social psychology, vol. 4, p. 719, 1995.

[7] J. H. \&. M. L. A. Kim, "The impacts of physical exercise on stress coping and wellbeing in university students in the context of leisure," Health, vol. 6, p. 2570, 2014.

[8] P. K. P. \&. I. E. S. Sari, "Hubungan antara dukungan sosial teman sebaya dengan resiliensi akademik pada mahasiswa tingkat akhir jurusan $\mathrm{x}$ fakultas teknik universitas diponegoro," Empati, vol. 5, pp. 177-182, 2017. 
[9] A. S. \&. D. M. A. Yasin, "The relationship between social support and psychological problems among students," International Journal of Business and Social Science, vol. 1, 2010.

[10] E. P. Sarafino, Health psychology, biopsychosocial interactions, New York.: John willey \& sons. Inc, 2006.

[11] Palupi, L. S. Psychological Well-Being of Elderly People in Indonesia: Javanese Psychological Well-Being Perspective. Universitas Airlangga , 177-180 (2018)

[12] Zimet, G. The Multidimensional Scale of Perceived Social Support . Indiana University School of Medicine , 30-41 (1988)

[12] A. Riani, "Hubungan antara Dukungan Sosial dan Problem-Focused Coping dengan Psychological Well-Being pada Mahasiswa FIP UNY," Jurnal Riset Mahasiswa Bimbingan Dan Konseling, vol. 8, 2016.

[13] T. Ö. Y. \&. L. R. Gençöz, "Direct and indirect effects of social support on psychological well-being," Social Behavior and Personality: an international journal, vol. 32, pp. 449-458, 2004. 